\title{
Upaya Peningkatan Kesadaran Masyarakat Terhadap Benda Peninggalan Sejarah Lubang Jepang Di Kelurahan Gunung Pangilun Kecamatan Padang Kota Padang
}

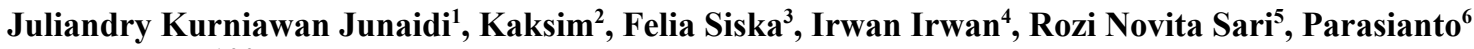 \\ ${ }^{1,2,3}$ Dosen Program Studi Pendidikan Sejarah, STKIP PGRI Sumatera Barat, \\ Kota Padang, Indonesia \\ ${ }^{4}$ Dosen Program Studi Pendidikan Sosiologi, STKIP PGRI Sumatera Barat, \\ Kota Padang, Indonesia \\ ${ }^{5,6}$ Mahasiswa Program Studi Pendidikan Sejarah, STKIP PGRI Sumatera Barat, \\ Kota Padang, Indonesia \\ Email: juliandry.junaidi@gmail.com¹, kaksim010983@gmail.com², feliasiska17@gmail.com³, \\ irwan7001@gmail.com ${ }^{4}$, rozinovitasari1998@gmail.com ${ }^{5}$,parasiantopsejarah@gmail.com6
}

\begin{abstract}
The purpose of community service is to provide knowledge, motivation and increase public awareness about the importance of maintaining historical awareness through the preservation of historical objects in the Japanese hole in Gunung Pangilun Village, North Padang District, Padang City. Methods of Community Service, namely conducting outreach to the community and evaluation consisting of before evaluating the activity, at the time it was carried out and at the end of the activity which was made notes and then recapitulated. The results of this service show that the community increases knowledge and awareness of the importance of historical sites in the area where they live. This encourages the role of the community, protection and preservation of the reserve in preserving history as a cultural relic of the past.
\end{abstract}

Keywords: Awareness Raising, Historical Relic, Japanese Hole

\begin{abstract}
Abstrak
Tujuan Pengabdian kepada masyarakat adalah memberikan pengetahuan, motivasi dan peningkatan kesadaran masyarakat tentang pentingnya memelihara kesadaran sejarah melalui pelestarian benda peninggalan sejarah lubang Jepang di Kelurahan Gunung Pangilun Kecamatan Padang Utara Kota Padang. Metode pelaksanaan Pengabdian Kepada Masyarakat yaitu melakukan sosialisasi kepada masyarakat dan evaluasi kegiatan yang terdiri dari evaluasi sebelum kegiatan, pada waktu kegiatan dilaksanakan dan diakhir kegiatan dibuat catatan kemudian direkap.. Hasil pengabdian tersebut menunjukan bahwa masyarakat termotivasi untuk peningkatan pengetahuan dan kesadaran akan pentingnya situs sejarah yang ada pada wilayah tempat mereka tinggal. Hal ini mendorong peran masyarakat, perlindungan dan pelestarian cagar budaya dalam pelesatrian sejarah sebagai peninggalan pada masa lampau.
\end{abstract}

Kata Kunci: Lubang Jepang, Peningkatan Kesadaran, Peninggalan Sejarah

\section{A. PENDAhULUAN}

Peristiwa masa lalu memberikan arti tersendiri bagi kehidupan manusia, salah satunya yaitu sejarah perjuangan bangsa Indonesia. Para pahlawan berjuang sampai titik darah penghabisan, mereka rela mengorbankan segalanya demi satu tujuan yaitu negara merdeka. Oleh sebab itu bangsa yang besar adalah bangsa yang menghargai jasa pahlawannya. Melalui pendidikan sejarah manusia akan memperoleh informasi tentang perjuangan pahlawan yang telah gugur dalam memperjuangkan kemerdekaan Indonesia.
Peristiwa yang terjadi masa lampau meninggalkan rekaman sejarah yang berupa fakta dalam bentuk artefak sejarah, yang harus selalu dirawat, tidak hanya dirawat secara fisik tetapi juga harus dirawat dalam ingatan yang ditandai dengan terbentuknya kesadaran sejarah. Benda-benda peninggalan sejarah dan purbakala merupakan peninggalan yang sangat penting bagi sebauah bangsa termasuk Indonesia. Di samping sebagai bukti kejayaan masa lalu benda-benda peninggalan sejarah dan purbakala dapat digunakan sebagai bahan untuk merekonstruksi masa lampau sehingga generasi sekarang dapat mengetahui identitas dirinya. Benda-benda peninggalan sejarah di 
Indonesia juga memberikan sumbangan penting dalam bidang kepariwisataan. Pemerintah sendiri telah memberi perhatian khusus pada benda-benda peninggalan sejarah tersebut mengingat arti pentingnya yaitu dengan dikeluarkannya UU No. 5 tahun 1992 mengenai benda cagar budaya. Tujuannya adalah untuk melestarikan benda-benda peninggalan sejarah dan purbakala yang keberadaannya semakin terancam. Kenyataan yang terjadi di masyarakat adalah bahwa masyarakat tidak atau belum memahami arti penting benda-benda peninggalan sejarah, sehingga ancaman terhadap keberadaan benda-benda peninggalan sejarah dan purbakala masih terus berlangsung. Beberpa masalah yang mengancam kelestarian benda cagar budaya oleh manusia antara lain:

1. Perusakan benda peninggalan sejarah, misalnya ahli fungsi penggunaan monumen sejarah

2. Merubah bentuk benda peninggalan sejarah.

3. Mencoret benda - benda peninggalan sejarah.

Pendidikan sejarah mengajarkan pada kita tentang perbuatan manusia di masa lampau. Dari perbuatan-perbuatan manusia tersebut kita dapat bercermin dan menilai perbuatan mana yang merupakan "keberhasilan" dan mana yang merupakan "kegagalan". Dengan demikian kita dapat lebih berhati-hati agar kegagalan itu tidak terjadi lagi (Rustam E. Tamburaka, 1999:43-44). Maka penting bagi suatu bangsa untuk memperdalam dan mempertegas pengertian sejarahnya yang dapat menyinari dan menghayati kepribadian nasional. Maka kita harus sadar dan waspada agar kepribadian nasional tidak dilepaskan dari jangkar kesadaran sejarah. Kesadaran sejarah merupakan suatu orientasi intelektual, suatu sikap jiwa yang perlu untuk memahami secara tepat paham kepribadian nasional. Kesadaran sejarah membimbing manusia mengenai diri sendiri sebagai bangsa, kepada self understanding of a nation, kepada sangkan paran suatu bangsa, kepada persoalan what we are, why we are. Kita juga memerlukan kesadaran sejarah supaya kita peka terhadap dimensi waktu didalam proses perwujudan suatu masyarakat dan kebudayaan baru (Soejatmoko, 1986:66-68). Budhisantoso (dalam Depdikbud, 1986:21-22) menjelaskan bahwa kesadaran sejarah penting dalam pembinaan budaya bangsa karena memerlukan dukungan dan peran serta secara aktif segenap anggota masyarakat. Untuk menggerakkan peran serta masyarakat dalam membina dan memperkembangkan kebudayaan nasional perlu dibangkitkan kesadaran bahwa mereka merupakan suatu kesatuan sosial yang terwujud melalui proses sejarah yang akhirnya mempersatukan sejumlah nasion kecil dalam suatu nasion Indonesia.

Lubang Jepang merupakan salah satu peninggalan bangsa Jepang di Indoneisa, Lubang
Jepang ini dibangun oleh Jepang untuk mengukuhkan jajahannya di Indonesia, walaupun dalam pembangunan lubang tersebut tenaga rakyat Indonesia diperas bahkan rakyat Indonesia dijadikan tenaga paksa dalam pembuatannya. Bahkan dalam pembuatan lubang jepang itu banyak menelan korban dari rakyat Indonesia, sarana lobang Jepang tersebut diguankan oleh Jepang sebagai tempatpersembunyian serta tempat menimbun alat-alat makanan dan alat persiapan untuk perang.

Di Sumatera Barat ada beberapa bekas peninggalan Jepang khususnya lubang Jepang, Lubang Jepang yang masih bagus perawatannya adlah lubang Jepang yang berada di Kota Bukittinggi, lubang Jepang ini dijadikan salah satu ikon wisata dari kota tersebut. Selain di daerah Bukittinggi itu ada beberapa lubang Jepang lainnya seperti di daerah Pasaman Barat ada beberapa buah lubang jepang di daerah Kecamatan Talamau, lubang Jepang ini berada ditepi jalan ketika arah menuju kecamatan Talamau khususnya daerah Talu.

Tepatnya di Kota Padang di daerah Kecamatan Padang Utara Kelurahan Gunung Pangilun ada beberapa peninggalan sejarah yaitu lubang Jepang yang merupakan bekas peningglan bangsa Jepang ketika menjajah Indonesia. Berdasarkan observasi dan wawancara dengan pemuka masyarakat gunung pangilun Lubang Jepang lebih kurang ada 20 buah. Lubang Jepang ini dibangun oleh bangsa Jepang untuk mengamankan mereka dari serangan musuh yaitu bangsa Indonesia. Padahal lubang itu dibuat atas bantuan tenaga rakyat Indonesia dengan memperkerjakan dengan paksa yang lebih dikenal kerja Romusha. Lubang Jepang yang ada di daerah Gunung Pangilun diperkirakan panjangnya lebih kurang 60 meter, lubang jepang yang dibuat ada fungsinya sebagai lubang pengintai untuk mngintai musuh yang akan datang, dan ada juga lubnag yang digunkan sebagai tempat penyimpanan bahan makanan, serta ada jga lubangnya dijadikan tempat persembunyian. Lubang yang dijadikan tempat persembunyian memiliki kamar-maka dan ada juga memiliki kamar mandi (wawancara dengan Darmawi St Sinaro, tanggal 19 Januari 2020). Pernyataan ini juga dipertegas oleh bapak Aris Chaniago yang mengatakan bahwa lubang Jepang ini panjangnya 60meter dan memilik kamar dan tangga. Bahkan kamar-kamarnya masih terkunci. Posisi lubang yang meiliki kamar ini letaknya ditengah rimba karena belum ada yang berani masuk ke lubang tersebut, Cuma melihat dari pintu depan saja.

Berdasarkan fenomena tersebut maka permasalahan ini cocok dijadikan sebagai tema pengabdian kepada masyarakat, terkait dengan Lubang Jepang di Daerah Gunung Pangilun Kecamatan Nanggalo Kota Padang, umumnya 
masyarakat tidak mengetahui bahwa di gunung pangilun ada benda peninggalan lubang Jepang.

\section{B. PELAKSAAAN DAN METODE}

Tempat dari kegiatan pengabdian kepada masyarakat ini adalah Kelurahan Gunung Pangilun Kecamatan Padang Utara Kota Padang khususnya lokasi tempat terdapatnya banyak lubang Jepang.

Pelaksanaan kegiatan ini terdiri dari beberapa tahap, Kegiatan pertama dilakukan yaitu dengan mengadakan pertemuan antara tim pelaksana kegiatan pengabdian kepada masyarakat yaitu dosen program studi pendidikan sejarah dan sosiologi, dengan merancang tempat kegiatan pengabdian, menentukan tahapan kegiatan serta teknis pelaksanaan kegiatan pengabdian kepada masyarakat. Kegiatan kedua menemui pimpinan atau pejabat yang berwenang untuk meminta izin untuk kesedian sebagai tempat pengabdian kepada masyarakat, Kegiatan selanjutnya tim dosen merancang jadwal, membuat surat menyurat sekaligus menyiapkan perlengkapan untuk kegaitan tersebut. Kemudian Persiapan tahapan akhir untuk menjelang diadakan kegiatan tersebut.

Ada dua metode yang akan digunakan dalam kegaiatan pengabdian ini antara lain:

1. Sosialisasi kepada masyarakat tentang pentingnya melestarikan peninggalan sejarah terutama peninggalan Jepang yaitu lubang jepang di Kelurahan Gunung Pangilun Kecamatan Padang Utara Kota Padang.

2. Evaluasi Kegiatan

Evaluasi terhadap pelaksanaan kegiatan dilakukan dengan langkah sebagai berikut:

a. Evaluasi sebelum kegiatan dilaksanakan berupa penjajakan pemahaman pemuka masyarakat dan masyarakat serta generasi muda tentang peninggalan bangsa Jepang yaitu adanya lubang jepang.

b. Pada waktu kegiatan dilaksanakan diberikan pemahaman untuk selalu melestarikan bekas peningalan sejarah khususnya lubang jepang yang ada di kelurahan Gunung Pangilun Kecamatan Padang Utara Kota Padang.

c. Diakhir kegiatan dibuat catatan kemudian direkap masukan dari masyarakat sebagai perbaikan untuk kegiatan pengabdian selanjutnya.

\section{HASIL DAN PEMBAHASAN}

\section{Hasil Pelaksanaan}

Kegiatan PPM ini dilaksanakan dengan beberapa tahapan:

\section{Observasi}

Observasi dilakukan beberapa kali: Pertama dilaksanakan untuk mengetahui letak situs cagar bersejarah Lubang Jepang. Kedua untuk mengetahui sekilas pemahaman dan respon masyarakat tentang situs bersejarah Lubang Jepang, pada tahap ini, tim PPM bertemu para pemuka masyarakat yang terdiri dari, Staf Kelurahan, serta masyarakat sekitar Gunung Pangilun diseputaran Lubang Jepang. Serta meninjau kembali situs bersejarah Lubang Jepang.

\section{Pelaksanaan}

Sosialisasi Pemberdayaan Masyarakat Tentang Pentingnya situs bersejarah mengadakan koordinasi dengan perangkat kelurahan terkait yaitu Bapak PLH kelurahan Gunung Pangilun Rizki Nur Zaidan, S. STP serta sekertaris kelurahan Padang Utara. Dalam kegiatan tersebut tim PPM menyampaikan beberapa hal sebagai berikut:

1. Pentingnya Masyarakat Kelurahan Gunung Pangilun menjaga situs bersejarah ini.

2. Dalam menjaga situs bersejarah masyarakat harus diberdayakan

3. Perbedayaan masyarakat ini penting untuk menumbuhkan kesadaran sejarah dalam menjaga monumen Lubang Jepang

4. Jika mampu dikelola dengan baik maka situs bersejarah ini tidah hanya bernilai edukatif juga bernilai ekonomis

5. Jika sudah mampu dikelola dengan baik oleh masyarakat maka akan berdampak terhadap perekonomian masyarakat.

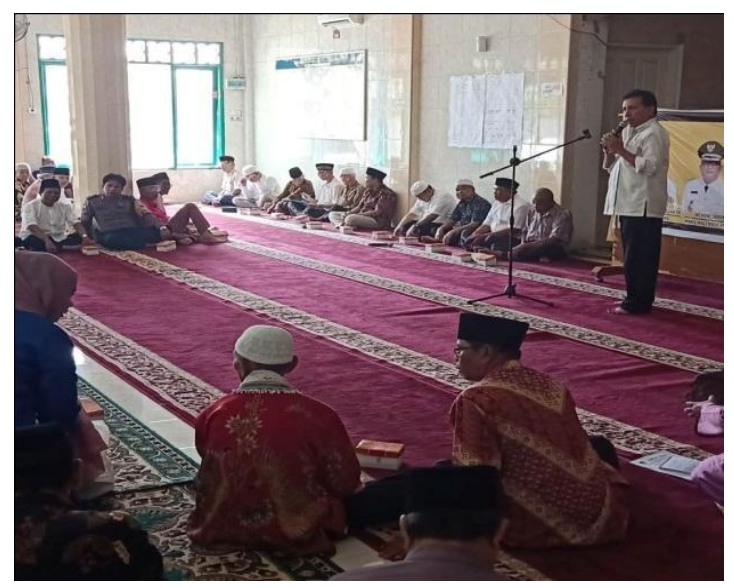

Gambar 1. Bersama Masyarakat dan Pemuka Masyarakat Gunung Pangilun

\section{Pembahasan}

Upaya-upaya penelitian dan pelestarian benda cagar budaya telah dimulai sejak Belanda berkuasa di Indonesia. Pada mulanya dilakukan secara perorangan yang tertarik dengan benda-benda purbakala yang baru dilihatnya. Perkembangan penemuan dan penelitian berikutnya mendorong Pemerintah Belanda 
mendirikan untuk pertama kalinya suatu badan sementara pada tahun 1901 yang bernama Commissie in Nederlandsch - Indie voor oudheidkundig onderzoek op Java en Madoera. Badan tersebut diganti Pada tahun 1913 dengan berdirinya Oudheidkundige Dienst in Nedelandsch - Indie sebagai badan tetap yang bertugas di bidang kepurbakalaan. Pada tahun 1913 ini pula dibuat Monumenten Ordonnantie No. 19 (Undang-Undang tentang Monumen) sebagai cikal bakal Undang-Undang yang mengatur kepurbakalaan di Indonesia. Selanjutnya diubah dengan Monumenten Ordonnantie No. 21 Tahun 1924. Pada tahun 1924 didirikan pula sebuah badan yang bernama Oudheidkundige Vereeniging Madjapahit yang berkedudukan di Trowulan yang bergerak khusus dalam lapangan penelitian terhadap ibukota Majapahit. Perjalanan penelitian dan pelestarian benda cagar budaya sempat terganggu dengan mendaratnya Jepang. Ahli-ahli purbakala Belanda banyak yang menjadi tawanan perang. Pada tahun-tahun berikutnya mulai muncul tenaga-tenaga purbakala dari Bangsa Indonesia yang akan memimpin Jawatan Purbakala.

Pada masa pergolakan kemerdekaan, Jawatan Purbakala berubah menjadi Jawatan Urusan Barang-Barang Purbakala. Kondisi peperangan yang terjadi dalam merebut dan mempertahankan kekuasaan antara Belanda dan Indonesia juga mempengaruhi penguasaan Jawatan Purbakala. Setelah terusirnya Belanda dari Indonesia menjadi babak baru bagi sejarah Jawatan Purbakala. Namun demikian, beberapa orang Belanda masih bekerja sampai dengan tahun 1953. Nama Jawatan Purbakala telah mengalami beberapa perubahan, antara lain Dinas Purbakala dan Lembaga Purbakala dan Peninggalan Nasional (LPPN). Pada tahun 1975 LPPN dipecah menjadi dua instansi, yaitu Pusat Penelitian Purbakala dan Peninggalan Nasional (PusP3N) dan Direktorat Sejarah dan Purbakala (DSP).

Pada tahun 1980 kembali diubah menjadi Pusat Penelitian Arkeologi Nasional (Puslitarkenas) dan Direktorat Perlindungan dan Pembinaan Peninggalan Sejarah dan Purbakala (Ditlinbinjarah). Sekarang ini, penggantian pemimpin negara atau presiden RI ternyata juga mempengaruhi perubahan yang terjadi di instansi yang bertugas di bidang penelitian dan pelestarian Benda Cagar Budaya ini. Perubahan yang terjadi sekarang malah terbagi menjadi tiga, yaitu Direktorat Peninggalan Purbakala, Direktorat Peninggalan Bawah Air, dan Pusat Penelitian Arkeologi. Sementara di daerah terdapat Unit

\section{PENUTUP}

\section{Simpulan}

Benda/situs cagar budaya merupakan salah satu tinggalan yang dimiliki oleh sebuah komunitas masyarakat. Cagar budaya tidak hanya
Pelaksana Teknis yang bernama Balai Arkeologi (Balar) yang berjumlah 10 buah dan Balai Pelestarian Peninggalan Purbakala (BP3) berjumlah 8 buah serta Balai konservasi Borobudur Selain membentuk jawatan atau dinas khusus dalam melestarikan benda cagar budaya, pada zaman orde baru muncul undang-undnag no.5 tahun 1992 tentang cagar budaya dan sekarang ini undang-undang no.11 tahun 2010. Keberadaan UU yang terbaru tentu saja untuk melengkapi maupun memperjelas UU sebelumnya dengan secara lebih mendetail menjabarkan makna pelestarian atau pemeliharaan dan perlindungan. Sosialiasi PPM tentang UU Cagar Budaya oleh Tim Prodi Pendidikan Sejarah dan Sosiologi STKIP PGRI Sumatera Barat menunjukkan peranan dunia akademik dalam menegakkan regulasi dan konservasi cagar budaya yang sesuai diagram 1 .

\section{Realisasi Pemecahan Masalah}

Kegiatan PPM merupakan upaya penyadaran masyarakat akan pentingnya situs sejarah yang ada dan mendorong peran masyarakat dan perlindungan dan pelestarian cagar budaya. Dalam penyampaian materi, tim PPM berusaha menggunakan kemampuan berkomunikasi dan cara persuasive serta pemahaman terhadap nilai-nilai yang ada pada khalayak sasaran di wilayah Gunung Pangilun.

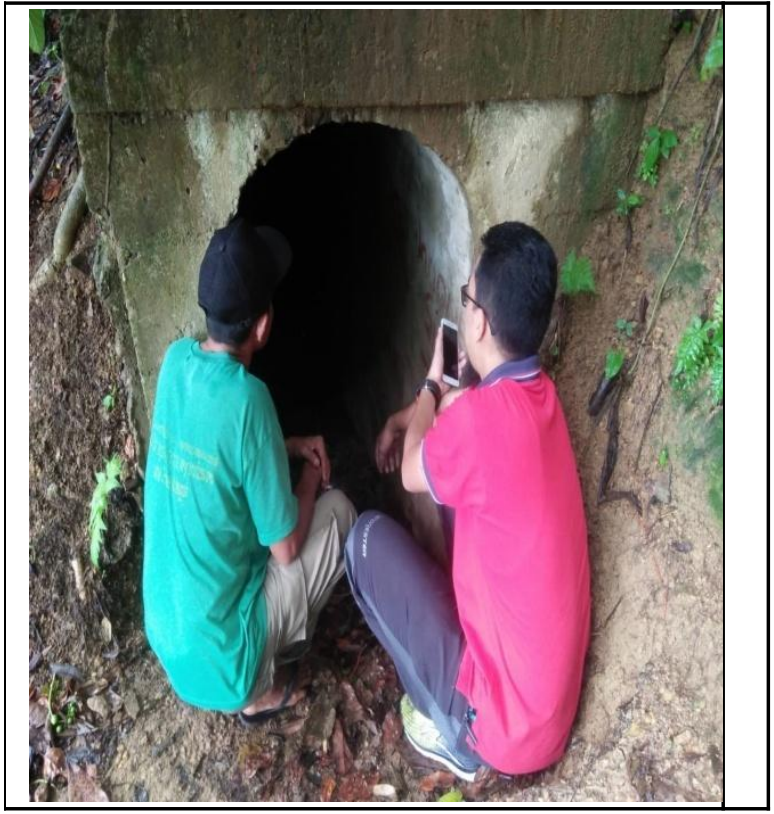

Gambar 2. Bersama Masyarakat Meninjau Situs Lubang Jepang Gunung Pangilun

menceritakan peradaban suatu masyarakat dalam suatu wilayah, tetapi juga perwujudan peradaban umat manusia. Nagari Pariangan memiliki banyak tinggalan benda/situs cagar budaya, namun tidak semua tinggalan tersebut dalam kondisi baik walaupun pembangunan dalam upaya pelestarian benda/situs cagar budaya telah dilaksanakan oleh 
pemerintah. Oleh karena itu, hasil penelitian senada dengan makalah yang ditulis oleh Sulistyanto (2014) mengatakan, perlu pelibatan masyarakat melalui upaya pemberdayaan. Tujuan pemberdayaan pada hakekatnya memampukan masyarakat agar dapat mengaktualisasi diri dalam pengelolaan lingkungan budaya yang terdapat di sekitarnya dan memenuhi kebutuhannya secara mandiri tanpa ketergantungan dengan pihak-pihak lain. Sasaran utama dari kegiatan. ini ialah masyarakat dan pemerintah Nagari Pariangan yang berada di sekitar benda/situs cagar budaya. Dasar penentuannya adalah bahwa masyarakat tersebut yang menerima dampak langsung dari kegiatan pengembangan benda/situs cagar budaya. Berangkat dari pandangan tersebut, kebijakan pemberdayaan diarahkan pada kemandirian masyarakat di Nagari Pariangan.

Upaya-upaya strategi pelestarian

benda/situs cagar budaya dalam pembangunan dapat dilakukan dengan pemberdayaan masyarakat nagari dan lembaga nagari. Untuk itu, strategi yang dapat dilakukan adalah dengan memberdayakan masyarakat nagari dan memperkuat struktur lembaga nagari. Kedua strategi tersebut jelas tidak terlepas satu dengan lainnya. Keduanya saling berhubungan. Adapun jalur yang ditempuh dapat dilakukan dengan tiga arah yaitu menciptakan suasana atau iklim yang memungkinkan potensi masyarakat berkembang (enabling), memperkuat potensi atau daya yang dimiliki oleh masyarakat (empowering), dan melindungi. Ketiga arah itu harus diperkuat dengan tiga program yaitu pengembagan sumber daya manusia (SDM) aparatur pemerintahan nagari dan masyarakat, program pengembagan kelembagaan nagari dan program pengembagan prasarana dan sarana serta kesejahteraan para aparatur pemerintahan nagari dalam upaya pelestarian benda/situs cagar budaya. Semua strategi, arah, dan program ataupun kegiatan akan berhasil apabila dilaksanakan secara terpadu dan berkesinambungan. Upaya-upaya strategi pelestarian benda/situs cagar budaya dalam pembangunan dapat dilakukan dengan pemberdayaan masyarakat nagari dan Lembaga nagari. Untuk itu, strategi yang dapat dilakukan adalah dengan memberdayakan masyarakat nagari dan memperkuat struktur lembaga nagari. Kedua strategi tersebut jelas tidak terlepas satu dengan lainnya. Keduanya saling berhubungan. Adapun jalur yang ditempuh dapat dilakukan dengan tiga arah yaitu menciptakan suasana atau iklim yang memungkinkan potensi masyarakat berkembang (enabling), memperkuat potensi atau daya yang dimiliki oleh masyarakat (empowering), dan melindungi. Ketiga arah itu harus diperkuat dengan tiga program yaitu pengembagan sumber daya manusia (SDM) aparatur pemerintahan nagari dan masyarakat, program pengembagan kelembagaan nagari dan program pengembagan prasarana dan sarana serta kesejahteraan para aparatur pemerintahan nagari dalam upaya pelestarian benda/situs cagar budaya. Semua strategi, arah, dan program ataupun kegiatan akan berhasil apabila dilaksanakan secara terpadu dan berkesinambungan.

\section{Saran}

Pengabdian ini memberikan saran kepada masyarakat untuk mengelola lingkungan budaya yang terdapat di sekitarnya dan memenuhi kebutuhannya secara mandiri tanpa ketergantungan dengan pihak-pihak lain.

\section{E. DAFTAR PUSTAKA}

Kuntowijoyo. 1994). Metode Sejarah, Yogjakarta: PT Tiara Wacana.

Marwati Djoened Poesponegoro dan Nugroho Notosusanto. (1992). Sejarah Nasional Indonesia: Zaman Jepang dan Zaman Republik Indonesia: Zaman Jepang dan Zaman Republik Indonesia, Jakarta: Balai Pustaka.

Moh Nazir. (1999). Metode Penelitian, Jakarta: Ghalia Indonesia.

Slamet Mulyana. (2008). Kesadaran Nasional: Dari Kolonialisme Sampai Kemerdekaan Jilid I, Yogjakarta: LKIS.

Taufik Abdullah. (1992). Nasionalisme Indonesia dari Asal Usul ke Prospek Masa Depan: Dalam Jurnal Sejarah No 8 Tahun 1992.

Undang-Undang No.5 Th 1992 Tentang Cagar Budaya. 